\title{
Confusion over Guidelines about Desirable Goals in Subjects with Diabetes, Hypertension and Dyslipidemia
}

\author{
Udaya M Kabadi* \\ Broadlawns Medical Center, University of Iowa, USA \\ *Corresponding author: Udaya M Kabadi, Adjunct Professor of Medicine, University of Iowa, Berkshire Parkway, Iowa, USA

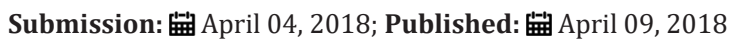

\section{Introduction}

Recently, American College of Physicians published new guidelines regarding desirable glycemic goal of $\mathrm{HbA1c}, 7-8 \%$ in subjects with type 2 diabetes [1]. Apparently, the guidelines are liberal or looser in comparison to those of $\mathrm{HbA1c}<6.5 \%$ or 7.0\% established by several organizations including American Association of Clinical Endocrinologists, American Diabetes Association, European Association for the Study of Diabetes, American Association of Diabetes Educators and Endocrine Society [2-5]. Moreover, the liberal glycemic guidelines are consistent with the policy of ACP regarding management of hyperglycaemia in hospitalized subjects, $140-200 \mathrm{mg} / \mathrm{dl}$ in contrast to $140-180 \mathrm{mg} /$ $\mathrm{dl}$ recommended by the same other organizations as well [6]. The efforts of these specialty organizations in refuting ACP guidelines are laudable. Finally, it is surprising that these multiple variable guidelines recommended by various organizations are apparently derived following examination and evaluation of the same data in the literature. Fortunately, all organizations recommend individualized glycaemia targets for individual subjects based on life expectancy, duration of the disorder, presence of micro and macro vascular complications and other co-morbidities as well as well as hypoglycaemia awareness.

It is also noteworthy that variable glycaemia guidelines are not an exception since variable guidelines; $120 / 80 \mathrm{~mm} \mathrm{Hg}$ vs. $140 / 90 \mathrm{~mm} \mathrm{Hg}$ are also recommended by various organizations in management of hypertension in subjects with diabetes $[7,8]$. Moreover, the guidelines for the desirable targets and therapies in management of dyslipdemia in subjects with diabetes are also neither uniform nor consistent. Thus, all these variable guidelines are certainly likely to create confusion amongst clinicians and patients alike [9-11]. Therefore, isn't it high time that all stake holders including all these organizations work together by forming a panel of experts to develop uniform and consistent guidelines regarding desirable targets for glycaemia, blood pressure and lipids in subjects with Diabetes as well as other chronic disorders following in depth examination of all available evidence in the literature?

\section{References}

1. Qaseem A, Wilt TJ, Kansagara D, Horwitch C, Barry MJ, et al. (2018) Hemoglobin A1c Targets for Glycemic Control With Pharmacologic Therapy for Nonpregnant Adults With Type 2 Diabetes Mellitus: A Guidance Statement Update From the American College of Physicians. Ann Intern Med.

2. Bailey TS, Grunberger G, Bode BW, Handelsman Y, Hirsch IB, et al. (2016) American college of endocrinology (ace) american association of clinical endocrinologists and American college of endocrinology 2016 outpatient glucose monitoring consensus statement. Endocr Pract 22(2): 231-261.

3. Bloomgarden ZT, Handelsman Y (2016) Approaches to treatment 2: Comparison of American Association of Clinical Endocrinologists (AACE) and American Diabetes Association (ADA) type 2 diabetes treatment guidelines. J Diabetes 8(1): 4-6.

4. Garber AJ, Abrahamson MJ, Barzilay JI, Blonde L, Bloomgarden ZT, et al. (2016) Consensus statement by the American association of clinical endocrinologists and american college of endocrinology on the comprehensive type 2 diabetes management algorithm--2016 executive summary. Endocr Pract 22(1): 84-113.

5. Cornell S (2017) Comparison of the diabetes guidelines from the ADA/ EASD and the AACE/ACE. J Am Pharm Assoc (2003) 57(2): 261-265.

6. Qaseem A, Humphrey LL, Chou R, Snow V, Shekelle P (2011) Use of intensive insulin therapy for the management of glycemic control in hospitalized patients: a clinical practice guideline from the American College of Physicians. Ann Intern Med 154 (4): 260-267.

7. Whelton PK, Carey RM, Aronow WS, Casey DE, Collins KJ, et al. (2017) 2017 ACC/AHA/AAPA/ABC/ACPM/AGS/APhA/ASH/ASPC/NMA/PCNA Guideline for the prevention, detection, evaluation, and management of high blood pressure in adults: a report of the American college of cardiology/American heart association task force on clinical practice guidelines. J Am Coll Cardiol pii: S0735-1097(17)41519-1.

8. Garber AJ, Abrahamson MJ, Barzilay JI, Blonde L, Bloomgarden ZT, et al. (2018) Consensus statement by the American association of clinical endocrinologists and American college of endocrinology on the comprehensive type 2 diabetes management algorithm - 2018 executive summary. Endocr Pract 24(1): 91-120. 
9. Lloyd Jones DM, Morris PB, Ballantyne CM, Birtcher KK, Daly DD, et al. (2017) 2017 Focused update of the 2016 acc expert consensus decision pathway on the role of non-statin therapies for LDL-cholesterol lowering in the management of atherosclerotic cardiovascular disease risk: a report of the American college of cardiology task force on expert consensus decision pathways. J Am Coll Cardiol 70(14): 1785-1822.

10. Garza L, Dols J, Gillespie M (2017) An initiative to improve primary prevention of cardiovascular disease in adults with type II diabetes based on the ACC/AHA (2013) and ADA (2016) guidelines. J Am Assoc Nurse Pract 29(10): 606-611.

11. Jellinger PS, Handelsman Y, Rosenblit PD, Bloomgarden ZT, Fonseca VA, et al. (2017) American association of clinical endocrinologists and American college of endocrinology guidelines for management of dyslipidemia and prevention of cardiovascular disease. Endocr Pract 23(Suppl 2): 1-87.

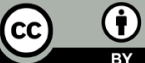

Creative Commons Attribution 4.0 International License

For possible submissions Click Here

\section{Submit Article}

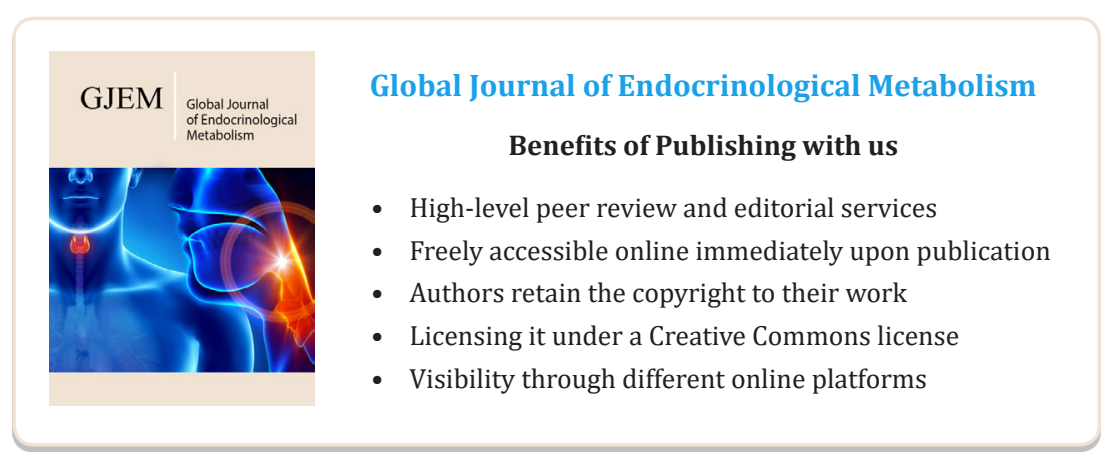

